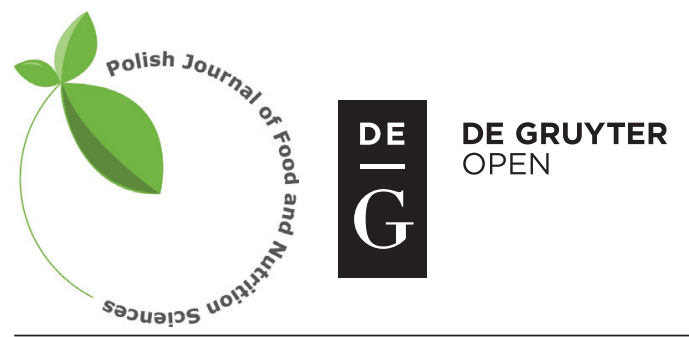

Pol. J. Food Nutr. Sci., 2016, Vol. 66, No. 3, pp. 199-209

DOI: $10.1515 /$ pjfns-2015-0044 http://journal.pan.olsztyn.pl

Original article

Section: Food Quality and Functionality

\title{
Kinetics of Texture and Colour Changes in Chicken Sausage During Superheated Steam Cooking
}

\author{
Asmaa A. Abdulhameed ${ }^{1,2 *}$, Tajul A. Yang ${ }^{1}$, A. A. Abdulkarim ${ }^{3}$
}

\author{
${ }^{1}$ Food Technology Division, School of Industrial Technology, Universiti Sains Malaysia, Minden 11800 Pulau Pinang Malaysia \\ ${ }^{2}$ Al-Adel Health Center, Al-Karkh Health Directorate, Ministry of Health, Bab Al-Mudam Area, Baghdad, Iraq \\ ${ }^{3}$ Chemical and Petrochemical Research Center, Commission for Research and Industrial \\ Development, Ministry of Industry and Minerals, Baghdad, Iraq
}

Key words: kinetics modelling, colour, texture, superheated steam cooking

The aim of this study was to develop a kinetic model to describe the texture and colour changes of chicken sausage during superheated steam cooking. Chicken sausages were cooked at temperature ranging from $150-200^{\circ} \mathrm{C}$ with treatment times ranging from $2-6$ mins. The texture profile was evaluated in terms of hardness, cohesiveness, gumminess, and chewiness, while the colour parameters were estimated in terms of lightness ( $\left.\mathrm{L}^{*}\right)$, redness $\left(\mathrm{a}^{*}\right)$, yellowness $\left(\mathrm{b}^{*}\right)$, and total colour difference $(\Delta \mathrm{E})$. Experimental data showed a gradual reduction in texture parameters as cooking times and temperatures increased. The $\mathrm{L}^{*}$ value of the colour showed a linear reduction with cooking condition, while the $\mathrm{a}^{*}, \mathrm{~b}^{*}$, and $\Delta \mathrm{E}$ values showed a contrary effects. The decrease in texture parameters and $\mathrm{L}^{*}$-value of colour parameter followed the first-order kinetic model. While, zero-order kinetic model was adapted to fit the $\mathrm{a}^{*}$ and $\mathrm{b}^{*}$. The modified first order kinetic showed a good fit for total $\Delta \mathrm{E}$. Significant correlations between colour and texture parameters were observed, which showed that a* alone could be used to predict the texture of chicken sausage.

\section{Nomenclature}

$\begin{array}{ll}\mathrm{C} & \text { quality attribute } \\ \mathrm{k} & \text { rate constant } \\ \mathrm{n} & \text { order of reaction } \\ \mathrm{R} & \text { gas constant }\left(8.314 \mathrm{~J} \mathrm{deg}^{-1} \mathrm{Mol}^{-1}\right) \\ \mathrm{T} & \text { absolute temperature }(\mathrm{K}) \\ \mathrm{t} & \text { time (min) } \\ \mathrm{Ea} & \text { activation energy }(\mathrm{kJ} / \mathrm{mol}) \\ \mathrm{C}_{\mathrm{eq}} & \text { the equilibrium value (maximum value or minimum value) } \\ \mathrm{RMS} \% & \text { of the quality attribute } \\ & \text { root mean square percent }\end{array}$

root mean square percent

$\begin{array}{ll}\mathrm{A}_{0} & \begin{array}{l}\text { pre-exponential factor } \\ \text { experimental value }\end{array} \\ \mathrm{C}_{\text {exp }} & \begin{array}{l}\text { calculated value } \\ \text { number of observations }\end{array} \\ \mathrm{C}_{\text {cal }} & \text { lightness value at zero time } \\ \mathrm{N}^{*} & \text { redness value at zero time } \\ \mathrm{L}^{*} & \text { yellowness value at zero time } \\ \mathrm{a}^{*} & \text { lightness value at time } \mathrm{t} \\ \mathrm{b}_{0}^{*} & \text { redness value at time } \mathrm{t} \\ \mathrm{L}^{*} & \text { yellowness value at time t } \\ \mathrm{a}^{*}{ }^{\mathrm{t}} & \text { total color difference } \\ \mathrm{b}^{*} & \end{array}$

including grilling, roasting, microwave oven cooking, deep frying, conventional oven cooking and boiling [Alina et al., 2012; Baggio \& Bragagnolo, 2006; Juárez et al., 2010; Serrano et al., 2007]. However, superheated steam may offer an alternative cooking method [Somjai et al., 2009]. The basic principle of this technique is the addition of sensible heat to the water; which leads to an increase in its temperature above the boiling point or saturation temperature at a given pressure. This then leads to the production of superheated steam [Abdulhameed et al., 2014].

Heat treatment strongly affects the texture, protein, and other important quality factors, such as the colour, flavour, and juiciness of the final product [Ayadi et al., 2009; Wattanachant et al., 2005]. Since texture is considered to be one of the most important indicators of food product \footnotetext{
quality, it is important to understand the physical changes

* Corresponding Author: Tel.: +60195940423;

E-mail: asmaa_alanee@yahoo.com (Asmaa A. Abdulhameed) 
of meat texture during heating. Protein denaturation reduces water holding capacity, shrinks muscle fibers, and causes connective tissue degradation, subsequently leading to a harder texture [Ovissipour et al., 2013]. The denaturation of actin and myofibrillar proteins decreases tenderness, while the gelatinization of connective tissue makes the meat tender again [Sanghoon et al., 2011].

Moreover, the measurement of colour in cooked meat could provide credible information on eating quality attributes. Various researchers have studied the colour change during cooking [Ramírez \& Cava, 2005; Ramírez et al., 2004]. Myoglobin protein is the major heme pigment that is responsible for meat colour, but there are other species which contribute to colour changes during processing such as deoxymyoglobin, oxymioglobin, metmyoglobin, and sulfmyoglobin. It has been found that during the cooking process three forms of myoglobin interconvert through oxygenation, oxidation-reduction reactions, and the browning reactions influence the final appearance of meat colour [García-Segovia et al., 2007; Saricoban \&Yilmaz, 2010].

One of the possible ways to control these alterations in texture and colour parameters during thermal treatment of food is by using a mathematical model. This may be achieved by assuming either zero or first-order kinetics [Jayendra Kumar et al., 2006]. To achieve the maximum food quality with minimum losses during thermal treatment, kinetic modeling is essential to derive the necessary basic kinetic information for a particular system to predict the reaction rate from the experimental data and hence, to predict variations in food quality during processing [Jaiswal et al., 2012; Rizvi \& Tong, 1997]. A considerable amount of researches have studied the kinetic changes in the texture and the colour during food processing. For instance, Chen et al. [2009] proposed the kinetics of texture changes of bologna sausage during cooking. Texture characteristic values were significantly affected by cooking conditions except for the adhesivenes. Statistical results showed that these kinetic models can be used $\left(\mathrm{R}^{2}>0.92\right)$ for the prediction of Bologna sausage texture properties within the range of experimental cooking conditions. Nourian \& Ramaswamy [2003] studied texture changes in potato during frying and cooking. They observed that the texture characteristic values were increased with cooking time and followed a first order kinetic model. While, Ateba \& Mittal [1994], suggested mathematical models describing kinetics of crust colour changes during deep-fat frying of meatballs. Crust colour decreased exponentially with frying time while total color change increased and followed the first order reaction.

Details on the kinetic analysis of the texture and colour changes of chicken sausage during superheated steam cooking have not been reported in the literature. Therefore, the present investigation was carried out to assess the textural and colour changes in chicken sausage during superheated steam cooking over a cooking temperature ranging from 150 to $200^{\circ} \mathrm{C}$ and cooking time ranging from 2 to $6 \mathrm{~min}$, in order to determine the kinetic parameters in terms of reaction rate constant and activation energy.

\section{MATERIAL AND METHODS}

\section{Sample preparation}

Ready-to-cook commercial chicken cocktail sausage was supplied from a local hypermarket. Each individual chicken sausage had approximately $58.14 \%$ moisture, $28.50 \%$ fat, $6.46 \%$ protein, $2.34 \%$ ash, and carbohydrate $4.56 \%$. The chicken cocktail sausage was packaged in 800 -g polyethylene bags and was transported directly to the laboratory. The chicken cocktail sausage was held under frozen conditions (-18 to $-20^{\circ} \mathrm{C}$ ) in a freezer. Then, chicken sausage was thawed at $4^{\circ} \mathrm{C}$ for $4 \mathrm{~h}$ until the cooking process [Muthia et al., 2010].

\section{Superheated steam oven cooking}

Each individual chicken sausage weighed approximately $11 \mathrm{~g}$ and was cooked using the SHARP superheated steam oven (AX-1500) with different temperatures (150, 160, $170,180,190$, and $200^{\circ} \mathrm{C}$ ). Treatment time varied between 2 and 6 min. All experiments were carried out in triplicate $(n=3)$. The samples were withdrawn periodically and analysed for texture and colour.

\section{Mathematical models and kinetic analysis}

A general reaction rate expression for kinetics of quality changes in foods can be written as follows [Jayendra Kumar et al., 2006].

$$
d C / d t=k C^{n}
$$

The order of the chemical reaction for texture and colour changes in chicken sausage is generally zero (Eq. 2) or first (Eq. 4)

$$
-\frac{d C}{d t}=k \quad(n=0)
$$

Eq. (2) could be integrated to obtain:

$$
\begin{aligned}
& C=C_{0}-k t \\
& -\frac{d C}{d t}=k C \quad(n=1)
\end{aligned}
$$

At integration, it gets:

$$
\ln \frac{C}{C_{\mathrm{o}}}=-k t
$$

In some cases (especially when the conventional first order model fails), the changes in quality parameters can be modeled using a modified first-order model based on the changes occurring between the initial and an equilibrium value (maximum or minimum) as follows (somtimes referred to as fractional conversion model). The rate constant is generally temperature dependent and the relationship can be quantified by the Arrhenius equation as indicated below: 


$$
\begin{aligned}
& C=\ln \left(C_{e a}-C_{t}\right)\left(C_{e a}-C_{0}\right) \\
& K=\mathrm{A}_{\mathrm{o}} \exp [-E a / R T]
\end{aligned}
$$

The activation energy $\left(\mathrm{E}_{\mathrm{a}}\right)$ and the preexponential factor $\left(A_{o}\right)$ could be obtained through linear regression of logarithm of the rate constant $v s$. the inverse of temperature. A steeper slope indicates that the reaction is more temperature sensitive, in which small changes in temperature produce a large change in rate constant. Again, when the rates decrease with temperature, a negative activation energy can arise from Eq. (7), in such cases, the negative sign in Eq. (7) is replaced with a positive sign and the associated activation energy must likewise be differentiated.

Root mean square percent (RMS \%) was quantified from the equation bellow:

$R M S(\%)=\sqrt{1 / N\left[\sum_{1}^{N}\left(\frac{C_{\text {exp }}-C_{c a l}}{C_{\exp }}\right)^{2}\right]} * 100$

where, $\mathrm{C}_{\text {exp }}$ and $\mathrm{C}_{\text {cal }}$ refer to experimental value and calculated value, respectively. Whereas, $\mathrm{N}$ refers to the number of experiments.

RMS also known as the quadratic mean was calculated to evaluate the accuracy of the fitted model between values predicted by a model or an estimator and the values actually observed.

\section{Texture analysis profile}

The texture profile for the prepared chicken sausage was measured using a texture analyser (Model TA. XT. Plus Texture Analyzer, UK). The prepared sample was cut into uniform $1.5 \mathrm{~cm}$ pieces. The texture profile analysis (TPA) was carried out in two compression cycles using a compression platen (SMS P/75) with a heavy duty platform with the following settings: load cell, $30 \mathrm{~kg}$; return distance, $30 \mathrm{~mm}$; return speed, $10 \mathrm{~mm} / \mathrm{s}$; contact force, $5 \mathrm{~g}$; prefixed strain, $75 \%$; pre-test speed $2.0 \mathrm{~mm} / \mathrm{s}$; time between compressing cycles was $2 \mathrm{~s}$. The texture analysis results were automatically performed by texture exponent software (version 32 Stable Micro Systems Ltd.), and the following parameters were recorded: hardness, cohesiveness, springiness, gumminess and chewiness. Hardness is the peak force (g) sensed on the first curve cycle. Cohesiveness is the ratio of the area under the second curve to the area under the first curve and relates to the sample strength of internal bonds. Springiness $(\mathrm{mm})$ is the force at maximum compressing during the second compression cycle. Gumminess is hardness multiplied by cohesiveness. Chewiness is gumminess multiplied by springiness [Briones-Labarca et al., 2012]. The texture profile analyses were carried out in triplicate for each sample.

\section{Colour measurement}

The prepared chicken sausage was cut into uniform $1.0 \mathrm{~cm}$ pieces. The surface colour of the prepared chicken sausage was measured using a colorimeter (Minolta Spectrophotometer CM-3500d, Osaka, Japan - Spectra Magic 3.61 software) with zero calibration. Then, it was calibrated with white calibration plate (CM-A120). The parameters measured in this analysis were $L^{*}, a^{*}$ and $b^{*}$. The $L^{*}$ value represents lightness and is a measure of the light intensity of a sample ( $L=100$ is the lightest and $L=0$ is the darkest); $\mathrm{a}^{*}$ value or redness stands for the chromatic scale from green colour (negative $a^{*}$ value) to red colour (positive $\mathrm{a}^{*}$ value); and $b^{*}$ value known as yellowness stands for the chromatic scale from blue colour (negative $b^{*}$ value) to yellow colour (positive $b^{*}$ value). Total colour differences $(\Delta)$ of chicken sausage were calculated using the following equation:

$$
\Delta \mathbf{E}=\sqrt{\left(\mathrm{L}_{0}-\mathrm{L}^{*}\right)^{2}+\left(\mathrm{a}_{0}-\mathrm{a}^{*}\right)^{2}+\left(\mathrm{b}_{0}-\mathrm{b}^{*}\right)^{2}}
$$

The colour measurements were performed at room temperature $\left(20 \pm 2^{\circ} \mathrm{C}\right)$ about $30 \mathrm{~min}$ after cooking processing.

\section{Statistical analysis}

Each experiment was done in triplicate and average values were taken for the analysis. Two-way ANOVA was used to find whether the effects of different cooking variables (time and temperature) of superheated steam oven and their interactions on texture and colour characteristics of chicken sausage were significant $(\mathrm{P}<0.05)$. Kinetic data were analysed by regression analysis using MS Excel package.

\section{RESULTS AND DISCUSSION}

\section{Kinetic data for texture during cooking conditions}

Texture is one of the most significant quality constraints, which is essential for ensuring product acceptability. According to De Man [1976], texture can be defined as "the way in which the structural components of food could be arranged into micro and macrostructure and the external manifestations for that structure". The experimental data of all texture characteristics parameters (hardness, springiness, cohesiveness, gumminess, and chewiness) at different superheated steam cooking temperatures and times are shown in Table 1.

Among the texture parameters which were tested, hardness is the most important parameter to consumers as it determines the commercial value of meat products [Nurul et al., 2010]. Hardness can be related to the force necessary to break the food with the incisors during mastication. First order kinetic model (Eq. 5) was found to be appropriate for modeling the impact of cooking conditions on the changes in the hardness of the chicken sausage. To calculate the rate constant (k), In Hardness/Hardness ${ }_{\mathrm{o}}$ was plotted versus time at different temperatures (Figure $1 \AA$ ). The resulting values of $\mathrm{R}^{2}$ were higher than 0.96 and the calculated $\mathrm{k}$ values were $0.04-0.09$. It could be observed that the hardness decreased with both temperature and time. The initial hardness value was $5.69 \mathrm{~kg}$ and this gradually decreased to $3.53 \mathrm{~kg}$ at $200^{\circ} \mathrm{C}(6 \mathrm{~min})$. The reduction in the hardness value could be attributed to the softening in the connective tissue caused by the conversion of collagen to gelatin which improved meat tenderness [Dhanapal et al., 2012; Kong et al., 2008; Murphy \& Marks, 2000]. Similarly García-Segovia [2008], also found that the hardness value decreased as the temperature and time 
TABLE 1. Kinetic of texture changes for chicken sausage during superheated steam cooking.

\begin{tabular}{|c|c|c|c|c|c|c|c|}
\hline \multirow{2}{*}{ Texture characteristics } & \multirow{2}{*}{ Temperature $\left({ }^{\circ} \mathrm{C}\right)$} & \multicolumn{6}{|c|}{ Time (min) } \\
\hline & & 0.00 & 2.00 & 3.00 & 4.00 & 5.00 & 6.00 \\
\hline \multirow{6}{*}{ Hardness $(\mathrm{kg})^{1}$} & 150 & $5.69 \pm 0.08$ & $5.19 \pm 0.09$ & $5.10 \pm 0.09$ & $4.90 \pm 0.09$ & $4.86 \pm 0.09$ & $4.69 \pm 0.05$ \\
\hline & 160 & $5.69 \pm 0.08$ & $5.12 \pm 0.05$ & $4.90 \pm 0.02$ & $4.86 \pm 0.03$ & $4.49 \pm 0.01$ & $4.30 \pm 0.16$ \\
\hline & 170 & $5.69 \pm 0.08$ & $4.92 \pm 0.14$ & $4.87 \pm 0.19$ & $4.19 \pm 0.13$ & $3.96 \pm 0.15$ & $3.86 \pm 0.14$ \\
\hline & 180 & $5.69 \pm 0.08$ & $4.88 \pm 0.01$ & $4.84 \pm 0.6$ & $4.06 \pm 0.06$ & $3.76 \pm 0.03$ & $3.67 \pm 0.07$ \\
\hline & 190 & $5.69 \pm 0.08$ & $4.87 \pm 0.04$ & $4.82 \pm 0.03$ & $4.42 \pm 0.07$ & $3.68 \pm 0.09$ & $3.47 \pm 0.03$ \\
\hline & 200 & $5.69 \pm 0.09$ & $4.85 \pm 0.05$ & $4.82 \pm 0.02$ & $4.06 \pm 0.05$ & $3.94 \pm 0.05$ & $3.53 \pm 0.002$ \\
\hline \multirow{6}{*}{ Cohesiveness (ratio) $^{1}$} & 150 & $0.90 \pm 0.09$ & $0.85 \pm 0.01$ & $0.82 \pm 0.04$ & $0.80 \pm 0.07$ & $0.79 \pm 0.002$ & $0.76 \pm 0.04$ \\
\hline & 160 & $0.90 \pm 0.09$ & $0.83 \pm 0.05$ & $0.82 \pm 0.04$ & $0.80 \pm 0.08$ & $0.77 \pm 0.01$ & $0.73 \pm 0.06$ \\
\hline & 170 & $0.90 \pm 0.09$ & $0.81 \pm 0.003$ & $0.81 \pm 0.01$ & $0.79 \pm 0.03$ & $0.76 \pm 0.02$ & $0.72 \pm 0.03$ \\
\hline & 180 & $0.90 \pm 0.09$ & $0.80 \pm 0.01$ & $0.77 \pm 0.03$ & $0.76 \pm 0.04$ & $0.73 \pm 0.01$ & $0.72 \pm 0.008$ \\
\hline & 190 & $0.90 \pm 0.09$ & $0.80 \pm 0.06$ & $0.79 \pm 0.01$ & $0.75 \pm 0.05$ & $0.72 \pm 0.01$ & $0.71 \pm 0.01$ \\
\hline & 200 & $0.90 \pm 0.09$ & $0.77 \pm 0.06$ & $0.74 \pm 0.07$ & $0.74 \pm 0.06$ & $0.71 \pm 0.08$ & $0.71 \pm 0.01$ \\
\hline \multirow{6}{*}{ Gumminess $(\mathrm{kg})^{1}$} & 150 & $2.94 \pm 0.07$ & $2.54 \pm 0.02$ & $2.39 \pm 0.01$ & $2.39 \pm 0.03$ & $2.27 \pm 0.4$ & $1.97 \pm 0.04$ \\
\hline & 160 & $2.94 \pm 0.07$ & $2.54 \pm 0.004$ & $2.31 \pm 0.04$ & $2.17 \pm 0.03$ & $2.00 \pm 0.13$ & $1.87 \pm 0.04$ \\
\hline & 170 & $2.94 \pm 0.07$ & $2.34 \pm 0.07$ & $2.22 \pm 0.09$ & $2.11 \pm 0.01$ & $1.78 \pm 0.07$ & $1.78 \pm 0.02$ \\
\hline & 180 & $2.94 \pm 0.07$ & $2.19 \pm 0.10$ & $2.10 \pm 0.06$ & $2.06 \pm 0.19$ & $1.39 \pm 0.01$ & $1.36 \pm 0.04$ \\
\hline & 190 & $2.94 \pm 0.07$ & $2.16 \pm 0.01$ & $2.09 \pm 0.01$ & $1.96 \pm 0.07$ & $1.39 \pm 0.07$ & $1.14 \pm 0.05$ \\
\hline & 200 & $2.94 \pm 0.07$ & $2.13 \pm 0.01$ & $1.74 \pm 0.05$ & $1.70 \pm 0.006$ & $1.59 \pm 0.04$ & $1.06 \pm 0.04$ \\
\hline \multirow{6}{*}{ Chewiness $(\mathrm{kg} / \mathrm{mm})^{1}$} & 150 & $2.69 \pm 0.11$ & $2.38 \pm 0.01$ & $2.26 \pm 0.01$ & $2.16 \pm 0.18$ & $2.12 \pm 0.18$ & $1.84 \pm 0.25$ \\
\hline & 160 & $2.69 \pm 0.11$ & $2.14 \pm 0.13$ & $1.98 \pm 0.13$ & $1.84 \pm 0.02$ & $1.74 \pm 0.06$ & $1.72 \pm 0.02$ \\
\hline & 170 & $2.69 \pm 0.11$ & $2.10 \pm 0.17$ & $1.79 \pm 0.22$ & $1.54 \pm 0.02$ & $1.29 \pm 0.23$ & $1.28 \pm 0.25$ \\
\hline & 180 & $2.69 \pm 0.11$ & $2.10 \pm 0.07$ & $1.72 \pm 0.11$ & $1.54 \pm 0.21$ & $1.29 \pm 0.04$ & $1.27 \pm 0.004$ \\
\hline & 190 & $2.69 \pm 0.11$ & $2.02 \pm 0.10$ & $1.79 \pm 0.01$ & $1.53 \pm 0.01$ & $1.27 \pm 0.09$ & $1.27 \pm 0.02$ \\
\hline & 200 & $2.69 \pm 0.11$ & $1.98 \pm 0.01$ & $1.69 \pm 0.01$ & $1.51 \pm 0.04$ & $1.20 \pm 0.01$ & $1.20 \pm 0.02$ \\
\hline
\end{tabular}

${ }^{1}$ Data are expressed as mean \pm standard deviation, $n=3$.

increased due to starch gelatinization during the cooking process. As well, chicken sausage with a high water content (>50\%) had lower shear stress and hardness, this result was also confirmed by Chang \& Carpenter [1997].

To calculate the pre-exponential factor $\mathrm{A}_{0}$ and the activation energy $\left(\mathrm{E}_{\mathrm{a}}\right)$ of the texture parameters, the values of $(\ln k)$ were plotted against $(1 / \mathrm{T})$ as presented in Figure 2. This figure shows the Arrhenius plot for the texture profile in temperatures ranging from 150 to $200^{\circ} \mathrm{C}$. It was observed that the values of $(\ln k)$ were increased with temperature for all texture parameters. From the straight line of this plot, the pre-exponential factor $\mathrm{A}_{0}$, the correlation coefficient $\mathrm{R}^{2}$, and the activation energy $\left(\mathrm{E}_{\mathrm{a}}\right)$ of the texture parameters were obtained. In which, the $\mathrm{E}_{\mathrm{a}}$ and $\mathrm{A}_{0}$ were calculated from the slope and intercept of the straight line, respectively.

The values of $\mathrm{A}_{0}$ and $\mathrm{E}_{\mathrm{a}}$ are shown in Table 2. As listed in this table, the activation energy was found to be $28.01 \mathrm{~kJ} / \mathrm{mol}$. Jayendra Kumar et al. [2006] observed that the activation energy of the hardness changes of the Gulabjamun ball during cooking was $60.80 \mathrm{~kJ} / \mathrm{mol}$. In addition, Nourian \& Ramaswamy [2003], found that the activation energy of hardness during frying of potato samples was $77.85 \mathrm{~kJ} / \mathrm{mol}$. The higher activation energy indicates that the hardness of the sample is not much sensitive to variations in cooking temperature [Jaiswal et al., 2012]. Therefore, the lower activation energy obtained here indicated that the hardness of the chicken sausage samples was highly sensitive to changes in temperature.

The resultant value of $\mathrm{R}^{2}$ was about 0.96 . The RMS calculated using Eq. (8) was 6.0, between the predicted and experimental data were well within the limit of experimental error (Table 2).

Figure 1B illustrates the changes in cohesiveness values during superheated steam cooking conditions. The cohesiveness values ranged from 0.90 to 0.71 (Table 1). It was found that there was a gradual decrease in the cohesiveness values with time in proportion to the cooking temperature. For such 

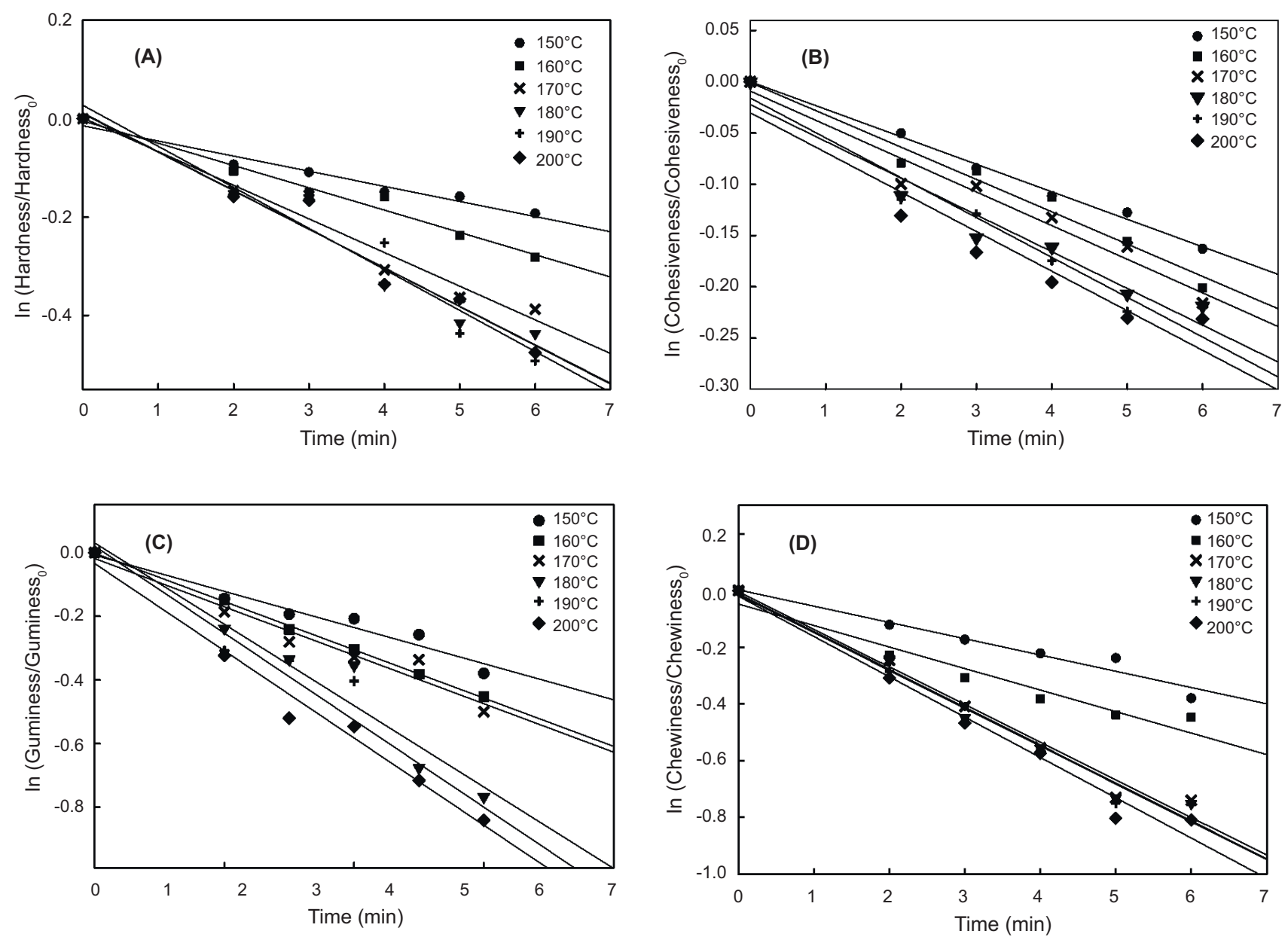

FIGURE 1. Changes in texture profile of chicken sausage during superheated steam cooking at different time-temperature: (A) hardness; (B) cohesiveness; (C) gumminess; and (D) chewiness.

TABLE 2. Summary of texture kinetics of chicken sausage during superheated steam cooking.

\begin{tabular}{lcccccc}
\hline $\begin{array}{l}\text { Order } \\
\text { of reaction }\end{array}$ & Parameters & $\begin{array}{c}\mathrm{E}_{\mathrm{a}} \\
(\mathrm{kJ} / \mathrm{mol})\end{array}$ & $\mathrm{A}_{\mathrm{o}}$ & $\mathrm{R}^{2}$ & $\begin{array}{c}\mathrm{RMS} \\
(\%)\end{array}$ \\
\hline First & Hardness & 28.01 & 127.74 & 0.96 & 6.0 \\
First & Cohesiveness & 26.76 & 51.42 & 0.98 & 2.09 \\
First & Gumminess & 32.97 & 692.76 & 0.99 & 6.38 \\
First & Chewiness & 29.56 & 349.09 & 0.98 & 9.60 \\
\hline
\end{tabular}

cases, the first order kinetic reaction was found to be adequate for modeling the changes of this parameter during the cooking process. The $\mathrm{R}^{2}$ values ranged between 0.93 and 0.99 , while the $\mathrm{k}$ values ranged from 0.02 to 0.06 . The pre-exponential factor and the activation energy were calculated by plotting $\ln \mathrm{k}$ versus $(1 / \mathrm{T})$ as in Figure 2. The activation energy $\mathrm{E}_{\mathrm{a}}$ was $26.76 \mathrm{~kJ} / \mathrm{mol}$, while $\mathrm{R}^{2}$ (0.98) and RMS (2.09) between the predicted and experimental data were well within the limit of experimental error (Table 2).

The secondary parameters of texture profile gumminess and chewiness followed the same pattern as that of hardness and cohesiveness as shown in Figure $1 \mathrm{C} \& \mathrm{D}$, respectively. It could be observed that the gumminess values which ranged

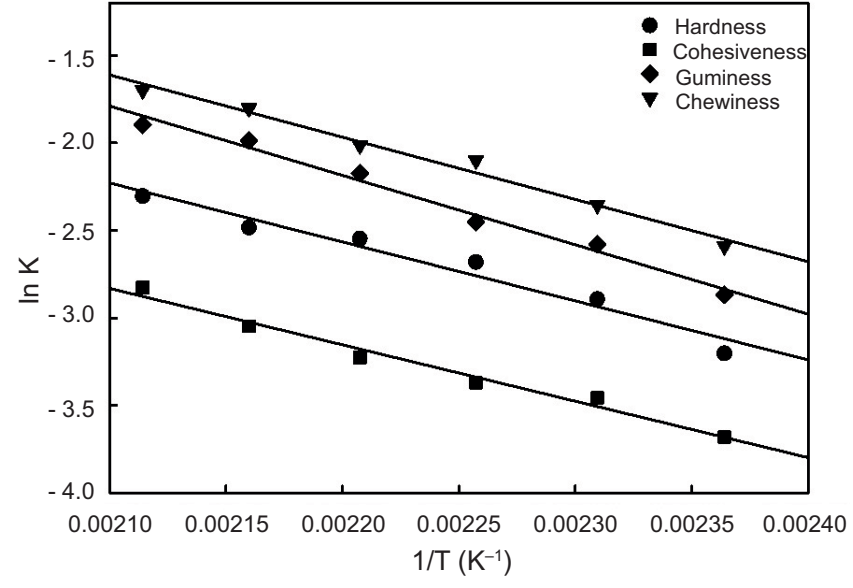

FIGURE 2. Arrhenius plot of the rate constants for texture changes of chicken sausage during superheated steam cooking.

from 2.94 to $1.06 \mathrm{~kg}$ and chewiness values which ranged from 2.69 to $1.20 \mathrm{~kg} / \mathrm{mm}$ were decreased with time in proportion to the cooking temperature. A correlation coefficient for both parameters were ranged from 0.95 to 0.99 and the k-value were $0.05-1.8$ and $0.06-.017$ respectively, thus confirming the change of these parameters to follow the first order kinetic as assumed. Figure 2 shows the exponential plot for 
TABLE 3. ANOVA of factors affecting texture kinetics of chicken sausage.

\begin{tabular}{|c|c|c|c|c|c|c|c|c|c|}
\hline \multirow{2}{*}{ Cooking variables } & \multirow{2}{*}{$\mathrm{df}$} & \multicolumn{2}{|c|}{ Hardness } & \multicolumn{2}{|c|}{ Cohesiveness } & \multicolumn{2}{|c|}{ Chewiness } & \multicolumn{2}{|c|}{ Gumminess } \\
\hline & & SS & $\operatorname{Pr}>F$ & SS & $\operatorname{Pr}>\mathrm{F}$ & SS & $\operatorname{Pr}>\mathrm{F}$ & SS & $\operatorname{Pr}>\mathrm{F}$ \\
\hline \multicolumn{10}{|l|}{ Independent: } \\
\hline Time (t) & 4 & 15.16 & $* * *$ & 0.08 & $* * *$ & 5.67 & $* * *$ & 7.83 & $* * *$ \\
\hline Temperature (T) & 5 & 6.73 & $* * *$ & 0.04 & $* * * *$ & 4.49 & $* * *$ & 4.89 & $* * *$ \\
\hline Interaction $\mathrm{t}^{*} \mathrm{~T}$ & 20 & 2.63 & $* * *$ & 0.01 & $* * *$ & 0.55 & $* * *$ & 1.18 & $* * * *$ \\
\hline
\end{tabular}

$* * *(\mathrm{P}<0.001)$.

TABLE 4. Kinetic of colour changes for chicken sausage during superheated steam cooking.

\begin{tabular}{|c|c|c|c|c|c|c|c|}
\hline \multirow{2}{*}{ Colour parameters } & \multirow{2}{*}{ Temperature $\left({ }^{\circ} \mathrm{C}\right)$} & \multicolumn{6}{|c|}{ Time (min) } \\
\hline & & 0.00 & 2.00 & 3.00 & 4.00 & 5.00 & 6.00 \\
\hline \multirow{6}{*}{$\mathrm{L}^{* 1}$} & 150 & $66.44 \pm 0.03$ & $66.39 \pm 0.07$ & $66.30 \pm 0.41$ & $66.25 \pm 0.28$ & $66.15 \pm 0.16$ & $66.08 \pm 0.02$ \\
\hline & 160 & $66.44 \pm 0.03$ & $66.30 \pm 0.15$ & $65.82 \pm 0.03$ & $65.51 \pm 0.08$ & $65.38 \pm 0.23$ & $65.25 \pm 0.40$ \\
\hline & 170 & $66.44 \pm 0.03$ & $66.35 \pm 0.24$ & $65.77 \pm 0.57$ & $65.74 \pm 0.81$ & $65.24 \pm 0.37$ & $65.16 \pm 0.36$ \\
\hline & 180 & $66.44 \pm 0.03$ & $66.35 \pm 0.82$ & $65.77 \pm 0.42$ & $65.74 \pm 0.42$ & $65.24 \pm 0.36$ & $65.16 \pm 0.51$ \\
\hline & 190 & $66.44 \pm 0.03$ & $66.07 \pm 0.18$ & $65.29 \pm 0.23$ & $64.73 \pm 0.92$ & $63.88 \pm 0.1$ & $63.46 \pm 0.13$ \\
\hline & 200 & $66.44 \pm 0.03$ & $63.81 \pm 0.14$ & $62.56 \pm 0.38$ & $60.74 \pm 0.13$ & $59.99 \pm 0.21$ & $58.96 \pm 0.16$ \\
\hline \multirow{6}{*}{$a^{* 1}$} & 150 & $8.82 \pm 0.18$ & $8.99 \pm 0.13$ & $9.32 \pm 0.01$ & $9.30 \pm 0.09$ & $9.48 \pm 0.27$ & $9.79 \pm 0.18$ \\
\hline & 160 & $8.82 \pm 0.18$ & $8.97 \pm 0.18$ & $9.11 \pm 0.25$ & $9.70 \pm 0.1$ & $9.71 \pm 0.1$ & $9.93 \pm 0.6$ \\
\hline & 170 & $8.82 \pm 0.18$ & $9.06 \pm 0.05$ & $9.34 \pm 0.3$ & $9.83 \pm 0.25$ & $9.98 \pm 0.7$ & $10.33 \pm 0.21$ \\
\hline & 180 & $8.82 \pm 0.18$ & $9.17 \pm 0.01$ & $9.79 \pm 0.29$ & $10.19 \pm 0.4$ & $10.68 \pm 0.5$ & $11.53 \pm 0.5$ \\
\hline & 190 & $8.82 \pm 0.18$ & $9.96 \pm 0.07$ & $10.37 \pm 0.37$ & $11.30 \pm 0.28$ & $11.90 \pm 0.07$ & $12.14 \pm 0.11$ \\
\hline & 200 & $8.82 \pm 0.18$ & $10.16 \pm 0.67$ & $10.45 \pm 0.29$ & $11.45 \pm 0.66$ & $11.83 \pm 0.09$ & $12.48 \pm 0.11$ \\
\hline \multirow{6}{*}{$b^{* 1}$} & 150 & $16.03 \pm 0.4$ & $16.37 \pm 0.06$ & $16.45 \pm 0.22$ & $16.87 \pm 0.17$ & $16.93 \pm 0.16$ & $17.21 \pm 0.22$ \\
\hline & 160 & $16.03 \pm 0.4$ & $16.33 \pm 0.29$ & $16.56 \pm 0.07$ & $16.96 \pm 0.09$ & $17.01 \pm 0.40$ & $17.17 \pm 0.48$ \\
\hline & 170 & $16.03 \pm 0.4$ & $16.45 \pm 0.17$ & $16.90 \pm 0.31$ & $17.23 \pm 0.23$ & $17.67 \pm 0.16$ & $18.39 \pm 0.44$ \\
\hline & 180 & $16.03 \pm 0.4$ & $16.60 \pm 0.31$ & $17.66 \pm 0.39$ & $17.78 \pm 55$ & $18.62 \pm 0.27$ & $19.52 \pm 0.66$ \\
\hline & 190 & $16.03 \pm 0.4$ & $17.54 \pm 0.14$ & $18.31 \pm 0.1$ & $19.05 \pm 0.17$ & $19.70 \pm 0.27$ & $20.22 \pm 0.15$ \\
\hline & 200 & $16.03 \pm 0.4$ & $18.19 \pm 0.43$ & $18.68 \pm 0.21$ & $20.06 \pm 0.55$ & $20.93 \pm 0.22$ & $21.04 \pm 0.17$ \\
\hline \multirow{6}{*}{$\Delta \mathrm{E}$} & 150 & $0.00 \pm 0.02$ & $0.38 \pm 0.08$ & $0.66 \pm 0.04$ & $0.98 \pm 0.16$ & $1.15 \pm 0.14$ & $1.56 \pm 0.05$ \\
\hline & 160 & $0.00 \pm 0.02$ & $0.36 \pm 0.15$ & $0.86 \pm 0.03$ & $1.58 \pm 0.13$ & $1.69 \pm 0.10$ & $1.98 \pm 0.12$ \\
\hline & 170 & $0.00 \pm 0.02$ & $0.49 \pm 0.02$ & $1.21 \pm 0.05$ & $1.71 \pm 0.10$ & $2.33 \pm 0.21$ & $3.08 \pm 0.22$ \\
\hline & 180 & $0.00 \pm 0.02$ & $0.76 \pm 0.11$ & $2.21 \pm 0.05$ & $2.80 \pm 0.06$ & $4.08 \pm 0.15$ & $5.32 \pm 0.36$ \\
\hline & 190 & $0.00 \pm 0.02$ & $2.78 \pm 0.04$ & $4.02 \pm 0.09$ & $5.29 \pm 0.03$ & $6.69 \pm 0.04$ & $8.18 \pm 0.14$ \\
\hline & 200 & $0.00 \pm 0.02$ & $3.65 \pm 0.04$ & $4.97 \pm 0.17$ & $7.45 \pm 0.07$ & $9.71 \pm 0.02$ & $9.71 \pm 0.06$ \\
\hline
\end{tabular}

${ }^{1}$ Data are expressed as mean \pm standard deviation, $n=3$.

gumminess and chewiness changes at different temperatures. The activation energy for the gumminess and chewiness were 32.97 and $29.65 \mathrm{~kJ} / \mathrm{mol}$, respectively. The values of $\mathrm{R}^{2}(0.99)$ and RMS (6.38) between the predicted and experimental data for these parameters are given in Table 2. It was shown that the decrease in the texture parameters with time in proportion to the cooking temperature fitted more with first order kinetic, and this was in agreement with the study of Jayendra Kumar et al. [2006], in which they observed that the first order reaction was more fitted to the reduction in texture parameters. 
From the previous analysis of texture parameters, it was observed that the behaviour of all the texture parameters with temperature fitted with the first order reaction kinetic. Similar finding was also observed by Jayendra Kumar et al. [2006], in which they found that the first order reaction was adapted to model the reduction of the texture parameters with temperature.

The reduction in the texture parameters with cooking time and temperature might be due to an increase in the denaturation of myosin and collagen as confirmed by other researchers [García-Segovia et al., 2008; Khan et al., 2014]. According to Verlinden et al. [1995], the decrease in textural characteristics during cooking resulted from a decrease in cell stiffness as the starch gelatinized and the cell wall bondings were weakened. In addition, it was observed that there was a remarkable reduction in the texture parameters after cooking due to the denaturation of proteins induced by cooking and also due to the uncoiling of polypeptide chains [Dhanapal et al., 2012].

An ANOVA of texture changes of chicken sausage as affected by the cooking variables (time and temperature) are presented in Table 3. The ANOVA analysis demonstrated that time and temperature had a significant influence on all the texture parameters $(\mathrm{P}<0.001)$. As well as, their interactions on the textural qualities of chicken sausage were highly significant $(\mathrm{P}<0.001)$.
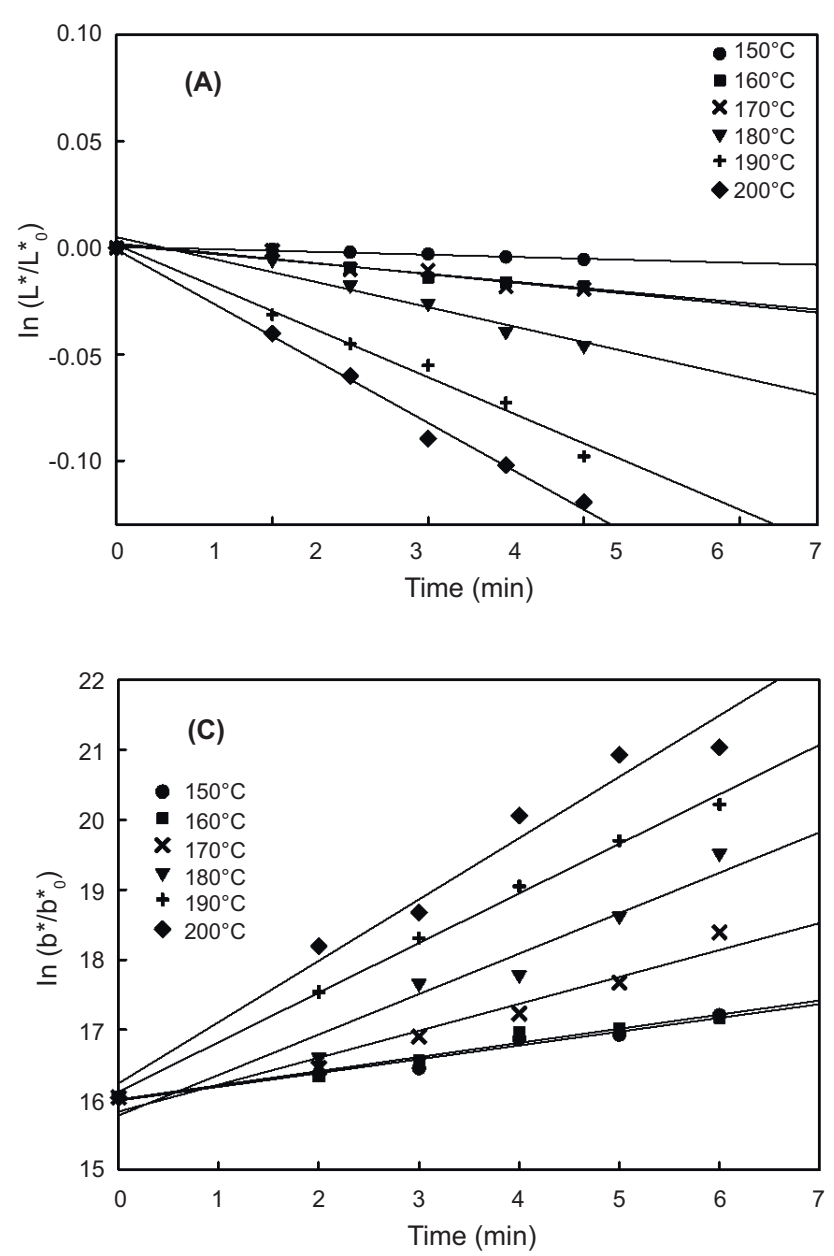

\section{Kinetic data of colour parameters}

The experimental data of all colour parameters $L^{*}, a^{*}$, $\mathrm{b}^{*}$ and $\Delta \mathrm{E}$ at different superheated steam cooking temperatures and times are shown in Table 4. Colour measurement in cooked meat could provide reliable information about eating quality attributes [García-Segovia et al., 2007]. A higher $\mathrm{L}^{*}$ value indicates a lighter colour, which is desirable in order to ensure that meat products will have high consumer acceptance [Resurreccion, 2004]. The changes of L* at six different temperatures were shown to follow the first-order reaction $(n=1)$ as seen in Figure $3 A$. In this figure, $\ln \mathrm{L}^{*} / \mathrm{L}_{\mathrm{o}}^{*}$ were plotted versus time at different temperatures to calculate the rate constant $(\mathrm{k})$. The resultant $\mathrm{R}^{2}$ was higher than 0.9 , while the k-values were from 9.42 to 0.02 . Also, Jayendra Kumar et al. [2006] demonstrated that the first order reaction was more appropriate to the decrease in lightness values.

It could be seen that there was a gradual decrease in the $\mathrm{L}^{*}$ value with temperature and time with an initial value of 66.44 . This value then reached a minimum of $200^{\circ} \mathrm{C}$ (58.96). This might be due to the development of the Millard reaction during cooking, in which the rate of this reaction depends on the composition of the product and the chemical environment [Jayendra Kumar et al., 2006; Ramírez et al., 2005]. Figure 4 shows the Arrhenius plot for the colour properties of the tested samples during superheated steam cooking
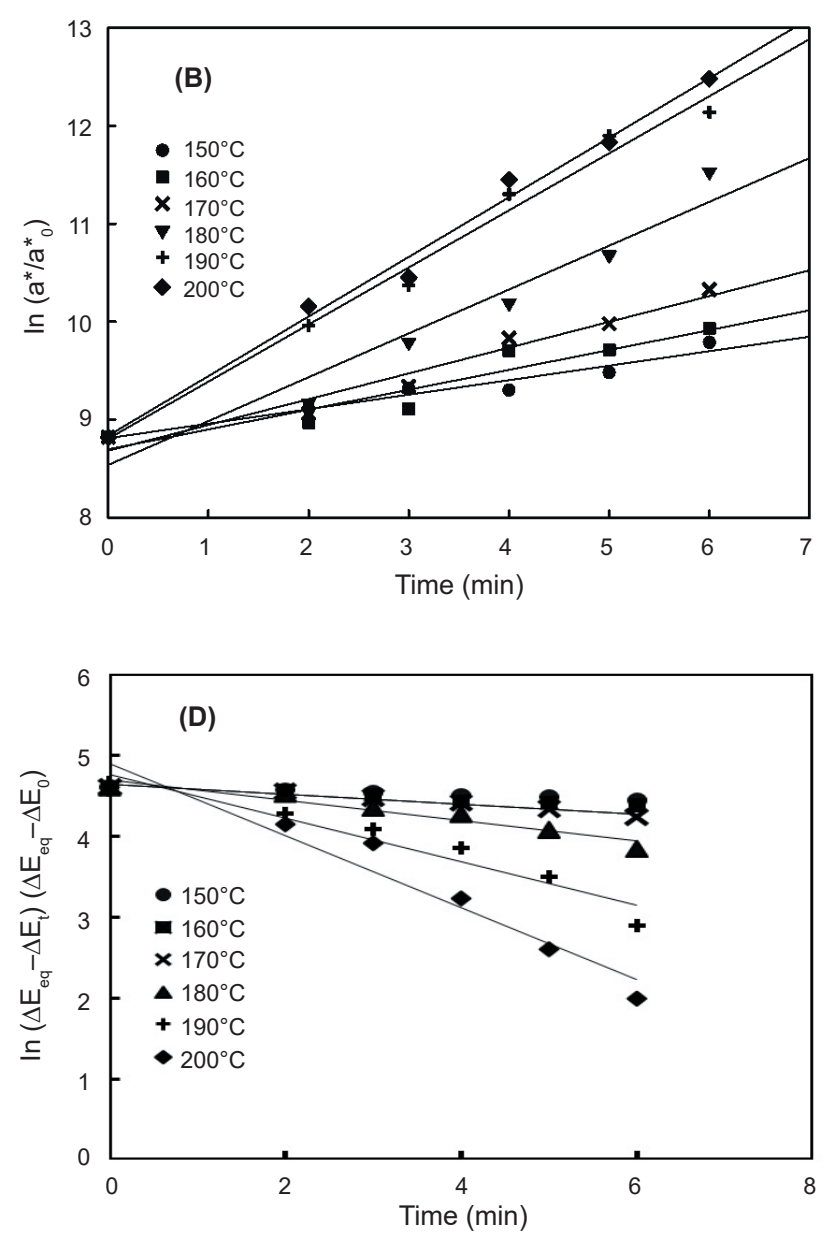

FIGURE 3. Changes in the colour properties of chicken sausage during superheated steam cooking at different time-temperature: (A) is lightness (L*); (B) is redness $\left(\mathrm{a}^{*}\right) ;(\mathrm{C})$ is yellowness $\left(\mathrm{b}^{*}\right)$; and $(\mathrm{D})$ is total colour differences $(\Delta \mathrm{E})$. 


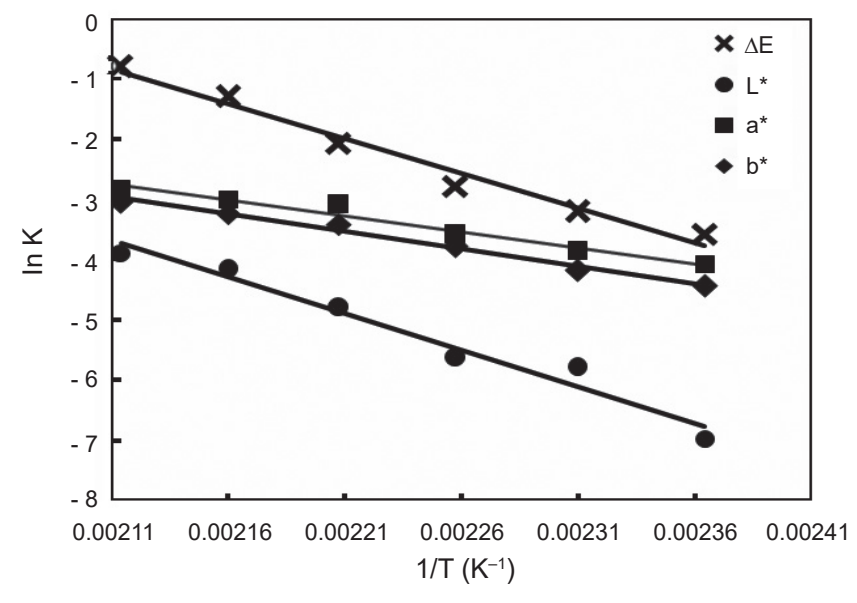

FIGURE 4. Arrhenius plot of the rate constants for colour changes of chicken sausage during superheated steam cooking.

TABLE 5. Summary of colour kinetics of chicken sausage during superheated steam cooking.

\begin{tabular}{|c|c|c|c|c|c|}
\hline $\begin{array}{l}\text { Order of } \\
\text { reaction }\end{array}$ & $\begin{array}{c}\text { Colour } \\
\text { parameters }\end{array}$ & $\begin{array}{c}E_{\mathrm{a}} \\
(\mathrm{kJ} / \mathrm{mol})\end{array}$ & $A_{o}$ & $\mathrm{R}^{2}$ & $\begin{array}{c}\text { RMS } \\
(\%)\end{array}$ \\
\hline First & $\mathrm{L}^{*}$ & 100.42 & $2.9^{*} 10^{9}$ & 0.97 & 1.51 \\
\hline Zero & $a^{*}$ & 51.33 & $3.24 * 10^{5}$ & 0.97 & 2.56 \\
\hline Zero & $b^{*}$ & 55.35 & $1.22 * 10^{6}$ & 0.98 & 1.39 \\
\hline $\begin{array}{l}\text { Modified- } \\
\text {-First }\end{array}$ & $\Delta \mathrm{E}$ & 95.90 & $2.49^{*} 10^{10}$ & 0.98 & 1.14 \\
\hline
\end{tabular}

in the temperatures ranging from 150 to $200^{\circ} \mathrm{C}$. It was found that the lnk values were clearly increased with treatments temperature for all colour parameters. From the straight line of this plot, the pre-exponential factor $\mathrm{A}_{0}$, the correlation coefficient $\mathrm{R}^{2}$, and the activation energy $\left(\mathrm{E}_{\mathrm{a}}\right.$ ) of the colour parameters were obtained. In which, the $\mathrm{E}_{\mathrm{a}}$ values were also calculated from the slope of the straight line, while $\mathrm{A}_{0}$ values were also calculated from the intercept of the straight line as indicated in Table 5.

As shown in Table 5, the activation energy of the lightness $\left(\mathrm{L}^{*}\right)$ was about $100.42 \mathrm{~kJ} / \mathrm{mol}$ for the investigated samples. This value was higher than the activation energy during the frying of the tofu samples $(76.0 \mathrm{~kJ} / \mathrm{mol})$ [Baik \& Mittal, 2003], and meat balls $(16.92 \mathrm{KJ} / \mathrm{mol})$ [Ateba \& Mittal, 1994]. The higher activation energy here implies that the $\mathrm{L}^{*}$ is not much sensitive to the temperatures changes. These dis- crepancies in the activation energies among various studies might be attributed to the differences in product composition, and cooking methods, as well as to the reaction that occurs during cooking. The $\mathrm{R}^{2}(0.97)$ and RMS (1.5) values were well within the limits of experimental error (Table 5), thus indicating the reliability of the model.

As indicated in Table 4, the $\mathrm{a}^{*}$ increased with both temperature and time with an initial value of 8.82 and the maximum reached 12.48 at $200^{\circ} \mathrm{C}$ at $6 \mathrm{~min}$. Zero order kinetic model $(n=0)$ was found to be more adequate for modeling the changes in the $\mathrm{a}^{*}$ value of chicken sausage during cooking with $\mathrm{R}^{2}$ being higher than 0.9 , and with $\mathrm{k}$ value between 0.01 and 0.05 (Figure 3B). Also, Chutintrasri \& Noomhorm [2007] found that the zero order kinetic model described adequately the increase in a* values with heat treatment.

Figure 4 shows the Arrhenius plot of rate constants for the change in $\mathrm{a}^{*}$ during the superheated steam cooking of chicken sausage in the examined temperatures. The resultant values of $\mathrm{R}^{2}(0.97)$ and RMS (2.56) between the predicted and experimental data were well within the limit of experimental error (Table 5). The activation energy of the redness ( $\left.\mathrm{a}^{*}\right)$ value was found to be $51.33 \mathrm{~kJ} / \mathrm{mol}$. This value was higher than the $\mathrm{E}_{\mathrm{a}}$ value of colour changes in sesame seeds during roasting $(25.4 \mathrm{~kJ} / \mathrm{mol})$ [Kahyaoglu \& Kaya, 2006]. The higher $\mathrm{E}_{\mathrm{a}}$ value in our study indicates that the $\mathrm{a}^{*}$ of chicken sausage was not so sensitive to temperature changes.

The yellowness $\left(b^{*}\right)$ data parameters fitted into a zero order equation $(n=0)$ and plots were constructed (Figure 3C) to find the rate of yellowness changes for chicken sausage during various time-temperature cooking. It was observed (Table 4) that the $b^{*}$ parameter followed the same pattern as that of the $a^{*}$ parameter. The initial value of the $b^{*}$ was 16.03 and it increased to 21.04 at $200^{\circ} \mathrm{C}(6 \mathrm{~min})$. The fitting accuracy $\left(\mathrm{R}^{2}\right)$ was found to be higher than 0.96 with $\mathrm{k}$ values ranging from 0.01 to 0.04 at all temperatures.

The Arrhenius plot of rate constant for the change in $b^{*}$ parameter of chicken sausage during cooking in the temperature range of $150-200{ }^{\circ} \mathrm{C}$ is shown in Figure 4. From the linear plot the pre-exponential factor $\mathrm{A}_{\mathrm{o}}, \mathrm{R}^{2}$, and the Activation energy were obtained and their values are listed in Table 5. The presented values of fitting accuracy $\left(\mathrm{R}^{2}\right)$ and the RMS are indicative of the reliability of the kinetic model (Table 5). The activation energy was $55.35 \mathrm{~kJ} / \mathrm{mol}$ for the changes in the $\mathrm{b}^{*}$ value during time-temperature cooking, which was higher than the $\mathrm{E}_{\mathrm{a}}(14.18 \mathrm{~kJ} / \mathrm{mol})$ obtained in another study [Kahyaoglu \& Kaya, 2006].

TABLE 6. ANOVA of factors affecting colour kinetics of chicken sausage.

\begin{tabular}{|c|c|c|c|c|c|c|c|c|c|}
\hline \multirow{2}{*}{ Cooking variables } & \multirow{2}{*}{ df } & \multicolumn{2}{|c|}{$\mathrm{L}^{*}$} & \multicolumn{2}{|c|}{$a^{*}$} & \multicolumn{2}{|c|}{$b^{*}$} & \multicolumn{2}{|c|}{$\Delta \mathrm{E}$} \\
\hline & & SS & $\operatorname{Pr}>\mathrm{F}$ & SS & $\operatorname{Pr}>\mathrm{F}$ & SS & $\operatorname{Pr}>\mathrm{F}$ & SS & $\operatorname{Pr}>\mathrm{F}$ \\
\hline \multicolumn{10}{|l|}{ Independent: } \\
\hline Time (t) & 4 & 256.53 & $* * * *$ & 28.87 & $* * *$ & 55.58 & $* * * *$ & 143.23 & $* * *$ \\
\hline Temperature (T) & 5 & 98.96 & $* * * *$ & 77.63 & $* * *$ & 1.05 .96 & $* * * *$ & 431.06 & $* * * *$ \\
\hline Interaction $\mathrm{t}^{*} \mathrm{~T}$ & 20 & 25 & **** & 6.08 & $* * *$ & 11.46 & $* * * *$ & 44.92 & $* * *$ \\
\hline
\end{tabular}

$* * *(\mathrm{P}<0.001)$. 
TABLE 7. Correlations between colour and texture parameters of chicken sausage.

\begin{tabular}{|c|c|c|c|c|c|c|c|c|}
\hline & Hardness & Gumminess & Chewiness & Cohesiveness & $\mathrm{L}^{*}$ & $a^{*}$ & $b^{*}$ & $\Delta \mathrm{E}$ \\
\hline Hardness & 1 & & & & & & & \\
\hline Gumminess & $0.90^{* *}$ & $1.00^{4 * 4}$ & & & & & & \\
\hline Chewiness & $0.94^{* * *}$ & $0.90^{* *}$ & $1.00^{* *}$ & & & & & \\
\hline Cohesiveness & $0.88^{* *}$ & $0.94^{* * *}$ & $0.91^{* *}$ & 1 & & & & \\
\hline $\mathrm{L}^{*}$ & $0.56^{* *}$ & $0.7^{* *+}$ & $0.63^{*+*}$ & $0.64^{* * *}$ & 1 & & & \\
\hline$a^{*}$ & $-0.83^{* * *}$ & $-0.92^{* *}$ & $-0.83^{* *}$ & $-0.84^{* *}$ & $-0.81^{* *}$ & 1 & & \\
\hline$b^{*}$ & $-0.78^{* *}$ & $-0.9^{* *}$ & $-0.83^{* *}$ & $-0.83^{* *}$ & $-0.82^{* *}$ & $0.98^{* *}$ & 1 & \\
\hline$\Delta \mathrm{E}$ & $-0.75^{* *}$ & $-0.87^{* *+}$ & $-0.75^{* *}$ & $-0.78^{* *}$ & $0.89^{* *}$ & $0.97^{* *+}$ & $0.98^{* *+}$ & 1 \\
\hline
\end{tabular}

** Correlation is significant at the level of $(\mathrm{P}<0.01)$.

It could be seen that the changes in colour parameters (an increase in $a^{*}, b^{*}$, and a decrease in $L^{*}$ values) with an increase in both time and temperature might be due to the presence of globin hemochrome implied by increasing the redness of muscles, in which the iron is in $\left(\mathrm{Fe}^{2+}\right)$ form, and is normally dull red. Globin hemichrome with the iron in the $\left(\mathrm{Fe}^{3+}\right)$ form is largely accountable for the brown grey colour. The balance between hemichromes and hemochromes is influenced by the status of the meat before processing and other factors including, animal and maturity, species, and muscle type [Latif, 2010]. In another investigation, Osborn et al. [2003] found that metmyoglobin and ferrichemochrome could be reduced to form the oxymyoglobin pigment (which is responsible for the pink colour) under reducing conditions with enzymatic or non-enzymatic reactions. In addition, the presence of sodium chloride, phosphate, and the increase of $\mathrm{pH}$ results in a decrease in lightness, and an increase in the pink colour of cooked meat [Ahn \& Maurer, 1989; Brewer et al., 2001].

The total color difference $(\Delta \mathrm{E})$ determined using Eq.(9) was increased with the passage of time, and the changes were clearly temperature dependent. The maximum recorded values of $\Delta \mathrm{E}$ were in the range of 8.18-9.07. The increase in the total colour reflecting darkening of the crust could be attributed to the Maillard reaction. The changes of $\Delta \mathrm{E}$ at six different temperatures were shown to follow the modified first-order reaction as seen in Figure 3D. This behaviour is in agreament with the study of Nourian \& Ramaswamy [2003], in which they found that the increase in $\Delta \mathrm{E}$ followed the modified first order reaction. From this figure, the fitting accuracy $\left(\mathrm{R}^{2}\right)$ was found to be higher than 0.92 with $\mathrm{k}$ values ranging from 0.027 to 0.44 at all temperatures. The Arrhenius plot of $\Delta \mathrm{E}$ is shown in Figure 4, in which the pre-exponential factor $A_{o}$, fitting accuracy $\left(\mathrm{R}^{2}\right)$, and the Activation energy $\mathrm{E}_{\mathrm{a}}$ could be obtained and their values are listed in Table 5. In this table, the presented values of fitting accuracy $\left(\mathrm{R}^{2}\right)$ and the RMS are indicative of the reliability of the kinetic model. The obtained activation energy was $95.91 \mathrm{~kJ} / \mathrm{mol}$ for the changes in the $\Delta \mathrm{E}$ value during time-temperature cooking.

The ANOVA results for the different colour parameters of chicken sausage as affected by cooking variables (time and temperature) and their interaction are presented in Table 6. It was found that the individual effects of cooking temperature and time as well as their interaction on the co- lour properties of chicken sausage were highly significant $(\mathrm{p}<0.001)$.

\section{Correlations between texture and colour parameters}

The changes in terms of texture and colour of chicken sausage effected by the superheated steam condition exhibited clear correlations. The correlation matrix is presented in Table 7. It shows that all texture parameters; hardness, cohesiveness, gumminess, and chewiness were directly correlated with lightness $\left(\mathrm{L}^{*}, \mathrm{P}<0.01\right)$, and negatively correlated with redness $\left(a^{*}\right)$, yellowness $\left(b^{*}\right)$, and total colour differences $(\Delta \mathrm{E})$. Thus, the increasing surface darkening (or, browning) as reflected in the decreasing $\mathrm{L}^{*}$ and increaseing in $\mathrm{a}^{*}, \mathrm{~b}^{*}, \Delta \mathrm{E}$ values was accompanied by decrease in the texture parameters of the chicken sausages. Furthermore, it may be noted that the $a^{*}$ value had higher correlations with texture than $\mathrm{L}^{*}, \mathrm{~b}^{*}$, and $\Delta \mathrm{E}$, which suggests that $\mathrm{a}^{*}$ alone could reliably be used to predict the texture of superheated steam cooked chicken sausages.

\section{CONCLUSIONS}

The kinetics of texture and colour development of chicken sausage during superheated steam cooking was investigated using the classical reaction order. The texture properties of hardness, cohesiveness, gumminess, and chewiness decreased with time and temperature. These changes could be described by the first-order reaction. The activation energy of the texture profile of hardness, cohesiveness, gumminess, and chewiness, were 28.01, 26.76, 32.97, and $29.56 \mathrm{~kJ} / \mathrm{mol}$, respectively. The lightness $\mathrm{L}^{*}$ value of the colour parameter decreased with time and temperature and followed the first order kinetic. The redness $a^{*}$ and yellowness $b^{*}$ values increased well and were fitted by using the zero-order kinetic. The total colour differnce $\Delta \mathrm{E}$ increased and followed the modified first order kinetics. The activation energy of the colour parameters: $\mathrm{L}^{*}, \mathrm{a}^{*}, \mathrm{~b}^{*}$, and $\Delta \mathrm{E}$ were $100.42,51.33,55.35$, and $95.5 \mathrm{~kJ} / \mathrm{mol}$, respectively. The activation energies of the texture parameters were lower than that of the colour parameters, which indicated that the texture parameters were subjected to more changes with the cooking conditions. The colour changes were significantly correlated with the textural changes mainly the increase in $a^{*}$ values exhibiting a high correlation coef- 
ficient (0.83-0.92) with the decrease in texture parameters. The results could potentially be used for predicting the quality change during superheated steam cooking of chicken sausage for optimum product quality.

\section{ACKNOWLEDGEMENTS}

The research leading to these results has received financial support from the School of Industrial Technology, University Sains Malaysia.

\section{REFERENCES}

1. Abdulhameed A.A., Zzaman W., Yang T.A., Application of superheated steam in sample preparation (Chicken sausage) for determination of total fat, fatty acid and lipid oxidation. Food Sci. Technol., 2014, 2, 27-33.

2. Ahn D.U., Maurer A.J., Effects of added pigments, salt, and phosphate on color, extractable pigment, total pigment, and oxidation-reduction potential in turkey breast meat. Poultry Sci., 1989, 68, 1088-1099.

3. Alina A.R., Nurul Mawaddah A.H., Siti Mashitoh A., Shazamawati Z.H., Nurulhuda M.S., Ummi Syuhada H.S., Imtinan A.K., Effect of grilling and roasting on the fatty acids profile of chicken and mutton. World Appl. Sci., 2012, 17, 29-33.

4. Ateba P., Mittal G., Dynamics of crust formation and kinetics of quality changes during frying of meatballs. J. Food Sci., 1994, 59, 1275-1278.

5. Ayadi M., Makni I., Attia H., Thermal diffusivities and influence of cooking time on textural, microbiological and sensory characteristics of turkey meat prepared products. Food Bioprod. Process., 2009, 87, 327-333.

6. Baggio S.R., Bragagnolo N., The effect of heat treatment on the cholesterol oxides, cholesterol, total lipid and fatty acid contents of processed meat products. Food Chem., 2006, 95, 611-619.

7. Baik O., Mittal G., Kinetics of tofu color changes during deep-fat frying. LWT Food Sci. Technol., 2003, 36, 43-38.

8. Brewer M., Zhu L., Bidner B., Meisinger D., Mckeith F., Measuring pork color: effects of bloom time, muscle, $\mathrm{pH}$ and relationship to instrumental parameters. Meat Sci., 2001, 57, 169-176.

9. Briones-Labarca V., Perez-Won M., Zamarca M., Aguilera-Radic J.M., Tabilo-Munizaga G., Effects of high hydrostatic pressure on microstructure, texture, colour and biochemical changes of red abalone (Haliotis rufecens) during cold storage time. Innov. Food Sci. Emerg. Tech., 2012, 13, 42-50.

10. Chang H.C., Carpenter J.A., Optimizing quality of frankfurters containing oat bran and added water. J. Food Sci., 1997, 62, 194-197.

11. Chen C., Marcotte M., Taherian A., Kinetic modeling of texture properties of Bologna sausage under cooking conditions. Int. J. Food Prop., 2009, 12, 252-260.

12. Chutintrasri B., Noomhorm A., Color degradation kinetics of pineapple puree during thermal processing. LWT Food Sci. Technol., 2007, 40, 300-306.

13. De Man J.M., Mechanical properties of foods. 1976, in: Rheology and Texture in Food Quality (eds. J.M. De Man, P.W. Voisey, V.F. Pasper, D.W. Stanley). Westport: The AVI Publishing Company, pp. 8-27.
14. Dhanapal K., Reddy G.V.S., Naik B.B., Venkateswarlu, G. Reddy, A.D., Basu S., Effect of cooking on physical, biochemical, bacteriological characteristics and fatty acid profile of Tilapia (Oreochromis mossambicus) fish steaks. Arch. Appl. Sci. Res., 2012, 4, 1142-1149.

15. García-Segovia P., Andrés-Bello A., Martínez-Monzó J., Effect of cooking method on mechanical properties, color and structure of beef muscle (M. pectoralis). J. Food Eng., 2007, 80, 813-821.

16. García-Segovia P., Andrés-Bello A., Martínez-Monzó J., Textural properties of potatoes (Solanum tuberosum L., cv. Monalisa) as affected by different cooking processes. J. Food Eng., 2008, 88, 28-35.

17. Jaiswal A.K., Gupta S., Abu-Ghannam N., Kinetic evaluation of colour, texture, polyphenols and antioxidant capacity of Irish York cabbage after blanching treatment. Food Chem., 2012, 131, 63-72.

18. Jayendra Kumar A., Singh R., Patel A., Patil G., Kinetics of colour and texture changes in Gulabjamun balls during deep-fat frying. LWT Food Sci. Technol., 2006, 39, 827-833.

19. Juárez, M. Failla, S. Ficco, A., Peña, F. Avilés C., Polvillo O., Buffalo meat composition as affected by different cooking methods. Food Bioprod. Process., 2010, 88, 145-148.

20. Kahyaoglu T., Kaya S., Modeling of moisture, color and texture changes in sesame seeds during the conventional roasting. J. Food Eng., 2006, 75, 167-177.

21. Khaksar R., Moslemy M., Hosseini, H., Taslimi A., Ramezani A., Amiri Z., Sabzevari A., Comparison of lipid changes in chicken frankfurters made by soybean and canola oils during storage. Iran J. Vet. Res., 2010, 11, 154-163.

22. Khan M.A., Ali S., Abid M., Ahmad H., Zhang L.,Tume R.K., Zhou G., Enhanced texture, yield and safety of a ready-to-eat salted duck meat product using a high pressure-heat process. Innov. Food Sci. Emerg. Tech., 2014, 21, 50-57.

23. Kong F., Tang J., Lin M., Rasco B., Thermal effects on chicken and salmon muscles: Tenderness, cook loss, area shrinkage, collagen solubility and microstructure. LWT Food Sci. Technol., 2008, 41, 1210-1222.

24. Latif S.S., Effect of marination on the quality characteristics and microstructure of chicken breast meat cooked by different methods. Lucrări Ştiinţifice J., 2010, 54, 314-325.

25. Murphy R., Marks B., Effect of meat temperature on proteins, texture, and cook loss for ground chicken breast patties. Poultry Sci., 2000, 79, 99-104.

26. Muthia D., Nurul H., Noryati I., The effects of tapioca, wheat, sago and potato flours on the physicochemical and sensory properties of duck sausage. Int. Food Res. J., 2010, 17, 877-884.

27. Naveena B., Muthukumar M., Muthulakshmi L., Anjaneyulu A., Kondaiah N., Effect of different cooking methods on lipid oxidation and microbial quality of vacuum-packaged emulsion products from chicken. J. Food Process. Preserv., 2014, 38, 39-47.

28. Nourian F., Ramaswamy H., Kinetics of quality change during cooking and frying of potatoes: Part II. Color. J. Food Process Eng., 2003, 26, 395-411.

29. Nurul H., Alistair T., Lim H., Noryati I., Quality characteristics of Malaysian commercial beef frankfurters. Int. Food Res J., 2010, 17, 469-476.

30. Osborn H., Brown H., Adams J., Ledward D., High temperature reduction of metmyoglobin in aqueous muscle extracts. Meat Sci., 2003, 65, 631-637. 
31. Ovissipour M., Rasco B., Tang J., Sablani S., Kinetics of quality changes in whole blue mussel (Mytilus edulis) during pasteurization. Food. Res. Int., 2013, 53, 141-148.

32. Ramírez M.R., Cava R., Changes in colour, lipid oxidation and fatty acid composition of pork loin chops as affected by the type of culinary frying fat. LWT Food Sci. Technol., 2005, 38, 726-734.

33. Ramírez M.R., Morcuende D., Estévez M., Cava R., Effects of the type of frying with culinary fat and refrigerated storage on lipid oxidation and colour of fried pork loin chops. Food Chem., 2004, 88, 85-94.

34. Resurreccion A., Sensory aspects of consumer choices for meat and meat products. Meat Sci.,2004, 66, 11-20.

35. Rizvi A., Tong C., Fractional conversion for determining texture degradation kinetics of vegetables. J. Food Sci., 1997, 62, 1-7.

36. Sanghoon Ko S-HY, Suyong Lee, Seongho Cho, Kwang-Hwa Kim, Rina Hwanc, Effect of long low temperature-short high temperature cooking cycle on physicochemical properties of beef. Food Sci. Technol. Res., 2011, 17, 11-16.
37. Saricoban C., Yilmaz M.T., Modelling the effects of processing factors on the changes in colour parameters of cooked meatballs using response surface methodology. World Appl. Sci., 2010, 9, 14-22.

38. Serrano A., Librelotto J., Cofrades S., Sánchez-Muniz F.J, Jiménez-Colmenero F., Composition and physicochemical characteristics of restructured beef steaks containing walnuts as affected by cooking method. Meat Sci., 2007, 77, 304-313.

39. Somjai T., Achariyaviriya S., Achariyaviriya A., Namsanguan K., Strategy for longan drying in two-stage superheated steam and hot air. J. Food Eng., 2009, 95, 313-321.

40. Verlinden B.E, Nicolaï B.M, De Baerdemaeker J., The starch gelatinization in potatoes during cooking in relation to the modelling of texture kinetics. J. Food Eng., 1995, 24, 165-179.

41. Wattanachant S., Benjakul S., Ledward D.A., Effect of heat treatment on changes in texture, structure and properties of Thai indigenous chicken muscle. Food Chem., 2005, 93, 337-348.

Submitted: 2 November 2014. Revised: 11 April 2015. Accepted 30 June 2015. Published on-line: 11 May 2016. 